\title{
Paul Trepte
}

Ely Cathedral Choir

\section{Dziatalność chórów katedralnych w Anglii na przyktadzie Ely Cathedral Choir ${ }^{1}$}

Nasz chór cieszy się ogromnie z przyjazdu do Krakowa i możliwości reprezentowania swojej katedry, miasta, hrabstwa oraz kraju. Oczywiście każdy chór katedralny w Anglii działa w inny sposób, ale wszystkie mają wspólny cel - Opus Dei - i w tym względzie ich działalność jest równie ważna. Idea Opus Dei ma naturalnie swoje korzenie w tradycji monastycznej z jej stałymi „oficjami” (sprawowaniem modlitw). Aktualnie praktykowane obrzędy liturgiczne to: msze święte i modlitwy poranne (Jutrznie, ale tylko w kilku katedrach, nie w Ely) oraz - swoisty klejnot w koronie - pieśń wieczorna (Nieszpory).

Aby zobrazować działalność anglikańskiego chóru katedralnego, najlepiej będzie, jeśli opowiem o miejscach, w których pracowałem, jako że miejsca te dobrze charakteryzują cztery kontrastujące ze sobą standardy.

$\mathrm{Na}$ początek New College (Collegium Novum) w Oxfordzie (słynny chór Kolegium z równie słynnego miasta uniwersyteckiego). Kończyłem tutaj studia muzyczne i byłem asystentem organisty. Chór Collegium Novum występuje tylko w trakcie trwania roku akademickiego - to jest przez trzy trymestry - każdy trwa osiem tygodni - czyli przez okres trochę krótszy niż pół roku.

Chór składa się z chłopców, chórzystów zawodowych oraz chórzystów stypendystów college’u. Chór występuje podczas sześciu obrzędów liturgicznych w tygodniu (prawie zawsze podczas Nieszporów). W czasie mojej pracy z chórem chłopcy odbywali próby w południe od 12:00 do 13:00 - jest to pora dnia, w której głosy dobrze pracują, lepiej niż rano, kiedy odbywają się próby większości chórów, w tym chóru z Ely! Również przed każdym występem liturgicznym odbywa się godzinna próba chóru. Nieszpory śpiewane są wieczorem o godz. 18:30.

1 Wykład wygłoszony 24 listopada 2015 na Akademii Muzycznej w Krakowie w ramach sesji naukowej Muzyka Kościota anglikańskiego - wspólne źródto, odmienne tradycje? zorganizowanej w ramach XI Dni Muzyki Kościelnej przez Międzyuczelniany Instytut Muzyki Kościelnej w Krakowie. 
Chór Katedry Worcester (Worcester Cathedral Choir) - gdzie zachowano pełnię tradycji chóralnej. Aktualnie przy katedrze w Worcester działają trzy chóry: dwa chłopięco-męskie oraz jeden męsko-dziewczęcy.

Działalność jednego z tych chórów polega na dobrowolnym uczestnictwie, śpiewie raz w tygodniu w niedzielny wieczór (głównie podczas Nieszporów). Pozostałe dwa chóry można określić jako na wpół profesjonalne: tworzą je mężczyźni śpiewający wraz z towarzyszącymi głosami wysokimi - albo dziewcząt, albo chłopców - choć zdarza się, że chłopcy i dziewczęta śpiewają razem. Chór Katedry w Worcester śpiewa podczas liturgii siedem razy w tygodniu. Obecność dziewcząt w chórach katedralnych stała się normą dopiero w roku 1991 z chwilą wprowadzenia tego zwyczaju przez Katedrę w Salisbury.

Wszystkie trzy chóry z Worcester, zarówno chłopięce, męskie, jak i dziewczęcy, otrzymują wsparcie finansowe przeznaczone na cele edukacyjne kampusu szkoły podstawowej i średniej - The King's School. Kiedy pracowałem w Worcester, nie było jeszcze chóru dziewczęcego, ponieważ do szkoły uczęszczali sami chłopcy - 50 dojeżdzających i 50 zamieszkujących internat.

Chłopcy z chórów w Worcester tradycyjnie próby odbywają rano przed szkołą. Jest to najlepszy czas, ponieważ chórzyści mają wówczas jasne umysły, są w pełni sił i nic jeszcze nie zdążyło zepsuć im dnia! Dla dorosłych może to być trochę bardziej uciążliwa pora, zwłaszcza gdy są niewyspani. Musi minąć wtedy trochę czasu, aby głosy zaczęły właściwie pracować - dzieje się tak szczególnie w przypadku starszych chórzystów. Każdego wieczoru tuż przed liturgią odbywa się jeszcze krótka próba.

Kościól prafialny pw. Matki Bożej w Warwick (St. Mary’s Parish Church) wyjątkowe miejsce, w którym zachowano styl katedralnego śpiewu chóralnego, pomimo iż nie jest to katedra. Działa tu to chór oparty na zasadzie dobrowolnego uczestnictwa, powszechnie znany i podziwiany w Anglii. Tutaj miałem po raz pierwszy okazję nadzorować program i tutaj też uczyłem się fachu (oczywiście początkowo popełniając masę błędów!).

Obrzędy liturgiczne z udziałem chóru mają miejsce w piątkowe wieczory oraz w niedziele. Chłopcy, którzy uczęszczają do różnych szkół, odbywają jedną próbę w czwartki wieczorem. Początkujący chórzyści przychodzą wcześniej, by następnie ćwiczyć z całym zespołem, następnie wychodzą, a starsi chórzyści kontynuują próbę. Ta metoda podziału chórzystów według grup i stopni zaawansowania jest popularna w Stanach Zjednoczonych.

Chór Katedry św. Edmunda (St Edmundsbury Cathedral Choir) - katedra znajduje się ok. $20 \mathrm{~km}$ od Ely i Cambridge. Chór przy katedrze St Edmundsbury (dystrykt St Edmundsbury) jest kolejnym przykładem chóru ochotników. Nie jest dotowany ani poprzez dofinansowanie chórzystów dorosłych, ani przez rodziców dzieci. 
Kiedy rozpocząłem swoją pracę z tym chórem, głosy wysokie składały się z małych chłopców i nastoletnich dziewcząt. Byłem więc zdziwiony, że moim pierwszym zadaniem, według życzenia pracodawcy, było stworzyć głosy wysokie tylko z chłopców! Dało się to osiągnąć przez stopniowe wypieranie głosów żeńskich dziewcząt, które oprócz tego, że były chórzystkami, studiowały lub pracowały. Wprowadziłem wówczas poranne próby chóru dla chłopców, którzy uczęszczali do bardzo różnych szkół. Po próbie podwoziłem wielu z nich na lekcje.

Nieszpory śpiewano w piątek wieczorem, po czym następowała 90-minutowa pełna próba przed trzyczęściową liturgią - mszy, Jutrzni lub Nieszporów - która odbywała się w niedziele.

Chór Katedry w Ely (Ely Cathedral Choir) - w roku 1989, kiedy rozpocząłem tu pracę, katedra w Ely miała tylko jeden tradycyjny chór chłopięco-męski. Przejąłem wówczas kierownictwo chóru po dr. Arturze Willsie, który dyrygował nim prze prawie pół wieku. To jest właśnie nasz chór, z którym przyjechaliśmy dziś do Krakowa.

W katedrze w Ely działają obecnie cztery chóry: oprócz naszego są jeszcze trzy: chór dorosłych ochotników, chór dziewczęcy (wiek 13-18) oraz chór dziecięcy (chłopców i dziewcząt w wieku 7-12 lat).

Chóry katedry w Ely obsługują w sumie osiem liturgii w ciagu tygodnia (jedne Nieszpory - codziennie o 17:30 oraz jedną mszę świętą w niedziele rano), według przykładowego porządku chóralnego: dziewczęco-męski; chłopięcy; dziewczęcy; chłopięco-męski; chłopięco-męski; chłopięco-męski; chłopięco-męski; chłopięco-męski (DM; C; D; CM; CM; CM; CM; CM C=chłopięcy, M=męski, D=dziewczęcy).

Chłopcy (i dziewczęta) są obowiązkowo uczniami zamieszkującymi bursę szkolną. Śpiewają podczas trwania roku szkolnego. Mają obowiązek również pozostać w szkole do Wielkanocy i świąt Bożego Narodzenia. Mogą wyjechać do domów dopiero po uczestnictwie w Nieszporach Niedzieli Wielkanocnej oraz 25 grudnia.

Istnieją trzy korzyści płynące z obowiązku zamieszkiwania w internacie szkolnym: łatwość uczestnictwa w próbach przed lekcjami, kultywowanie ducha współpracy i wspólnoty (wszyscy chórzyści mieszkają w tym samym budynku) i zachowanie równowagi pomiędzy edukacją ogólną w szkole, rekreacją a pracą w chórze. Jest to bardzo ważne, zwłaszcza gdy piętrzą się obowiązki, na przyklad w okresie Adwentu, świąt Bożego Narodzenia czy Wielkanocy.

Chłopcy kochają życie w szkole i w bursie. To zasługa przede wszystkim wspaniałego grona opiekujących się nimi nauczycieli. Są z nami również dzisiaj rodzice chórzystów pracujący w szkole. Neil jest dyrektorem ds. muzyki w szkole podstawowej, a jego żona, Nicky, nauczycielką gry na wiolonczeli. 
W naszej szkole uczy się 22 chłopców oraz 18 dziewcząt. Wszyscy rodzice chłopców otrzymują 50-procentowy dodatek na pokrycie kosztów internatu i czesnego. 17 spośród 22 chłopców otrzymuje wsparcie finansowe z kapituły katedralnej (cathedral chapter); pozostałych pięciu wspierają finansowo władze szkolne, które również dofinansowują edukację dziewcząt, oferując im dodatek w wysokości min. 33\%.

Kiedy następuje zmiana głosów, dodatek jest nadal wypłacany, choć stawka jest niższa - wynosi 33\%.

Życie chóru katedralnego jest wymagające, ale bardzo ekscytujące. Będzie ono odpowiadało jednym chłopcom, a innym nie. Wydarzenia takie jak nagrania radiowe i telewizyjne, koncerty, wyjazdy zagraniczne (do USA, Kanady, Francji, Włoch, Hiszpanii, Holandii, Niemiec, Belgii, które do tej pory odwiedziliśmy - i oczywiście Polski) są jak „lukier na torcie”. Jednak wszyscy chórzyści pamiętają, że naszym głównym zadaniem pozostaje zawsze Opus Dei).

\section{Czas poznać nasz chór!}

Nasz chór tworzy sześciu mężczyzn - zawodowych śpiewaków zatrudnionych na stałe - oraz wielu dodatkowych chórzystów śpiewających w niedziele, pełniących także rolę chórzystów rezerwowych w razie potrzeby. Tu, do Krakowa, przybyło wraz z Edmundem Aldhousem (asystentem mojego organisty) i ze mną trzech z sześciu zatrudnionych chórzystów oraz trzech chórzystów dodatkowych.

\subsection{Prezentacja śpiewaków z imienia i profesji wraz z próbką śpiewu}

Od męskich śpiewaków wymagamy łatwości we współpracy, biegłości w czytaniu nut a vista, elastycznych godzin pracy. Często bywa tak, że mężczyźni zaczynają śpiewać jako chłopcy w chórze lub stypendyści uczelniani. Trzeba zapoznać ich z tradycją chóralną, tak aby zrozumieli pewne właściwe tylko dla niej zasady. Dobrym przykładem jest śpiewanie psalmu do melodii pieśni anglikańskiej.

\subsection{Chtopcy}

Podczas naszych podróży przekonaliśmy się, że chóry angielskich katedr budzą powszechny podziw na całym świecie, nie tylko ze względu na śpiew, ale także prowadzoną w nich dyscyplinę. Dobrze zdyscyplinowana grupa młodzieży zawsze robi wrażenie w dzisiejszych czasach, zwłaszcza w obliczu współczesnych trendów. Trzeba jednak pamiętać, że dyscyplina działa tylko wtedy, kiedy opiera się na samodyscyplin ie, a nie na czymś narzuconym z zewnątrz. 
Chłopcy uczą się dużo od dorosłych, z którymi śpiewają, i wolą, gdy traktuje się ich jak młodych profesjonalistów, a nie jak szkolnych uczniów, co przeważnie udaje się osiągnąć dorosłym. Osiągnięcia młodych śpiewaków biorą się ze stałego rytmu obejmującego codzienne uczestniczenie w obrzędach liturgicznych i z ćwiczeń na próbach.

Rekrutując nowych śpiewaków, poszukujemy kandydatów z wyrazistą osobowością, obiecującym głosem i słuchem. Szukamy potencjału, nie osiągnięć w siedmiolatku! Nasi chórzyści to normalni, psotni chłopcy! Nie są takim aniołami na jakich wyglądają! Oto kilka rzeczy, których nauczyłem się w przeciągu lat pracy z nimi:

- Chłopcy lubią zadowalać innych. Nie lubią zawodzić samych siebie.

- Jeśli powiesz chłopakowi, że potrafi coś zrobić, jakkolwiek trudne i skomplikowane by to nie było, on to zrobi. Na tym polega cała sztuczka!

- Chłopcy uwielbiają wyzwania i ciężką pracę.

- Potrafią śpiewać tak dobrze jak dorośli - ale też tak źle jak dorośli, jeśli nabiorą złych nawyków takich jak zła postawa ciała, płytki oddech, ściśnięte szczęki czy spięte ramiona.

- Chłopcy potrafią się śmiać, a cóż może być lepszego?

\subsection{Szkolenie chórzystów}

Nie jestem pewien, jak wiele sam mógłbym zdziałać, jeśli chodzi o budowanie brzmienia. Śpiewacy robią to sami, w dużej mierze poprzez naśladowanie i demonstrowanie - wielu moich kolegów szkolących chóry katedralne w Anglii stosuje podobną metodę.

Każdy głos jest oczywiście inny. Lubię porównywać głosy do instrumentów w orkiestrze - często odwołujemy się do tego porównania, kiedy omawiamy śpiew. Potrzebujemy wszystkich, przeróżnych instrumentów, aby utworzyć odpowiedni i słyszalny melanż głosowy.

Przedstawiamy także bardzo często partie solowe, dając pojedynczym śpiewakom szansę na to, by zabłysnęli, kiedy są na to gotowi.

Kluczem do sukcesu jest szkolenie najmłodszych chórzystów. Edmund, mój asystent, spędza wiele godzin z chłopcami, ćwicząc z nimi głównie czytanie nut. Jestem wielkim orędownikiem rzucania chłopców na głęboką wodę. W przeciągu kilku tygodni od wstąpienia do chóru, każdy chłopiec - nieważne jak młody - jest w stanie zaśpiewać kilka partii śpiewu w czasie nabożeństwa w kościele.

Wszyscy chłopcy mają indywidualne lekcje śpiewu z trenerem raz w tygodniu. Przywiązujemy dużą wagę do strony wokalnej, a nasi trenerzy głosu są częstymi gośćmi prób i występów. Prawdą jest, że niektórzy chłopcy są bardziej utalentowa- 
ni od innych w czytaniu nut. Jednak to zawsze tych kilku chłopców z zaawansowaną umiejętnością czytania nadaje tempo. Pozostali starają się i nadążają za nimi.

Zawsze zaczynamy od tekstu. Nie ma najmniejszego sensu w śpiewaniu (często w obcym języku, szczególnie po łacinie), jeśli wcześniej nie rozumie się słów. Zwracamy także uwagę na ich wymowę, tonację i siłę głosu. Jest to bardzo ważne, ponieważ wiąże się z wielkością i wymiarami budynku czy sali, w których przyjdzie nam śpiewać. Analizujemy też znaczenie słów, co wiążę się z kwestią ich komunikowania, a więc również z zadaniem chórzysty polegającym na przewodzenia nabożeństwu.

\subsection{Jak wygladaja nasze próby?}

Nie ma innych stałych zasad i porządku poza tymi, że:

- Na początek trzeba rozgrzać głosy (szczególnie wcześnie rano).

- Trzeba dokładnie wiedzieć, czym się zająć w tak krótkim czasie, i sprawdzać, czy wszystko zostało zrealizowane, nawet jeśli nie zdąży się skorygować wszystkich błędów.

- Należy pracować raczej w kreatywny niż sztucznie narzucony i normatywny sposób.

- Należy pracować wspólnie jako zespół, zachęcając do pytań i sugestii.

- Trzeba zachęcać chórzystów do rozpoznawania i przyznawania się do błędów (na przykład przez podniesienie ręki dla zasyganlizowania, że został popełniony błąd).

- Trzeba jak najczęściej chwalić chórzystów!

- Trzeba definiować problem i szukać jasno sformułowanych rozwiązań. Nie należy mówić „tu był fałsz”, a raczej: „To było zbyt ostre. Co możemy z tym zrobić?".

W kontekście całego śpiewu chóralnego jest wiele korzyści płynących z faktu bycia chórzystą katedralnym:

- Edukacja muzyczna: wszyscy chłopcy mają lekcje teorii i uczą się gry na co najmniej jednym instrumencie.

- Podziwianie piękna architektury świętego miejsca.

- Zanurzenie się w poezji psalmów.

- Opanowanie największego wroga: czasu (nauka efektywnego zarządzania czasem).

- Możliwość zadawania ważnych pytań (my nie indoktrynujemy, ale stymulujemy dociekliwe umysły).

Dobrze jest, gdy mamy pozytywne odczucia względem tego, co robimy. Ale nie byłoby w porząaku nie przyznać, że możemy mieć problem z rzeczami, które nas denerwują, takimi jak: 
- Postawa: „tyle muzyki do przerobienia co tydzień! Może da się jakoś to obejść?".

- Nieustające tempo rodzące zmęczenie.

- Tyle nut do opanowania. Nie jesteśmy biegli w śpiewaniu z pamięci i często zapominamy patrzeć na dyrygenta.

- Śpiewanie w chórze może sprawiać, że „chowamy się za” kopiami muzycznymi.

- Śpiewanie na koncercie jest mniej naturalne i może to mieć wpływ na wykonanie.

- Głosy chłopięce zmieniają się wcześniej. Kompozytorzy śpiewnika z ton, tworzący swoją muzykę w końcu XIV wieku (jak William Cornysh czy Robert Fairfax) pisali z myślą o chłopcach w wieku 18 do 20 lat (dlatego być może te kompozycje są tak wymagające). Bach tworzył z myślą o 17-, 18-letnich chłopcach. W dzisiejszych czasach głosy chłopięce ulegają zmianie w wieku lat 13 lub nawet wcześniej.

- I jeszcze jeden problem: chór to wydatek dla katedry!

\section{Zakończenie}

Miałem przyjemność zajmować się chórzystami przez całe swoje życie. Uwielbiam przygotowania, próby, a potem prawie codzienne występy. Czasem udaje się chórowi opanować dany utwór tak dobrze, że w jego śpiewie jest to coś. Wtedy czujemy, iż udało nam się sprawić, że zgromadzeni wierni „dotknęli na moment kawałka nieba”. Jeśli to nastąpi, możemy naprawdę powiedzieć, że wypełniło się Opus Dei.

tłum. Agnieszka Stańczyk

\section{Streszczenie}

Dziatalność chórów katedralnych w Anglii na przykładzie Ely Cathedral Choir

W wykładzie Paul Trepte zaprezentował sposób funkcjonowania chórów w anglikańskich katedrach w Wielkiej Brytanii. Wykładowi towarzyszyła demonstracja repertuaru wykonanego przez chór katedralny z Ely, a także prezentacja możliwości wokalnych chó- 
rzystów. Paul Trepte przedstawił również metodykę ćwiczenia i prowadzenia chóru chłopięcego, opierając się na długiej i bogatej tradycji anglikańskiej, podkreślając swoistą filozofię kształcenia młodych ludzi poprzez muzykę.

\section{Summary}

\section{Ely Cathedral Choir as an instance of activity of cathedral choirs in England}

In his lecture, the speaker Paul Trepte presented the model of choirs functioning at Anglican Cathedrals in Great Britain. The lecture was enhanced with a live demonstration of the repertoir, vocal sounds and voice capabilities of the Choir of the Ely Cathedral assisting the speaker. Mr Trepte presented as well the methodology of running and conducting a boys' choir, drawing on a long and rich Anglican tradition and accentuating the peculiar philosophy of educating young people through music.

Stowa kluczowe chór Collegium Novum, chór katedry Worcester, chór katedry św. Edmunda, chór katedry w Ely

Key words Worcester Cathedral Choir, Collegium Novum Choir, St Edmundsbury Cathedral Choir, Ely Cathedral Choir 